This item was submitted to Loughborough's Research Repository by the author.

Items in Figshare are protected by copyright, with all rights reserved, unless otherwise indicated.

\title{
Exploring the contribution of activity sports tourism to same-day visit expenditure and duration
}

PLEASE CITE THE PUBLISHED VERSION

https://doi.org/10.1080/14775085.2020.1784255

PUBLISHER

Taylor \& Francis (Routledge)

VERSION

AM (Accepted Manuscript)

PUBLISHER STATEMENT

This is an Accepted Manuscript of an article published by Taylor \& Francis in Journal of Sport and Tourism on 22 June 2020, available online: http://www.tandfonline.com/10.1080/14775085.2020.1784255.

\section{LICENCE}

CC BY-NC-ND 4.0

\section{REPOSITORY RECORD}

Downward, Paul, Simona Rasciute, and Cristina Muniz. 2020. "Exploring the Contribution of Activity Sports Tourism to Same-day Visit Expenditure and Duration". Loughborough University. https://hdl.handle.net/2134/12489911.v1. 


\section{Exploring the contribution of activity sports tourism to same-day visit}

\section{2 expenditure and duration}

3

4

5 Paul Downward*

6 School of Sport, Exercise and Health Sciences, Loughborough University, Loughborough,

7 LE11 3TU, UK, ORCID ID: 0000-0002-6374-4176.

8 Corresponding author*: p.downward@lboro.ac.uk

9

10 Simona Rasciute

11 School of Business and Economics, Loughborough University, Loughborough, LE11 3TU,

12 UK, ORCID ID: 0000-0003-2254-081X.

14 Cristina Muniz

15 Department of Economics, University of Oviedo, 33006, Oviedo, SPAIN, ORCID ID: 0000$16 \quad 0001-9935-8149$. 


\section{Exploring the contribution of activity sports tourism to}

\section{same-day visit expenditure and duration}

\title{
3 Abstract
}

4

\author{
Abstract
}

.

Drawing upon a unique large-scale data source $(n=5,004)$ and motivated by the time allocation model of consumer demand in economics, this paper critically analyses the relationship between the expenditure from, and duration of, same-day visits that comprise a large component of the domestic tourism market in England. It focusses on the contribution of activity sports tourism as a component of same-day visits. Three-stage least squares (3SLS) instrumental variable estimation is employed to account for the simultaneous determination of duration and expenditure as implied by economic theory. Controlling for socio-economic characteristics and general trip behaviours, the research identifies that although total expenditures and trip durations are positively related, there are trade-offs between these when focussing on the direct effects of the activities undertaken. However, accounting for the interrelationship between the duration of visits and the expenditures on them, it is found that walking reduces the expenditures on trips and their duration. Field sports increase them both. No effects are identified for running and cycling, as land-based activity sports tourism, or swimming and water sports, as water-based activity sports tourism.

The key drivers of expenditure, which also increase the duration of trips, are visiting attractions and hospitality. The research provides a theoretically informed and empirically robust foundation for a more nuanced and targeted activity sports tourism strategy, which might have implications for how activity sports tourism may contribute to health and wellbeing and local economic development to better inform tourism planning and policy.

Keywords: same-day visits; activity sport tourism; expenditure; duration; 3SLS regression; rural areas 


\section{Introduction}

Activity sports tourism is increasingly prominent in the sports tourism market (Sato et

al., 2018; Whitehead \& Wicker, 2018) and refers to either sports tourism defined as 'all forms

of active and passive involvement in sporting activity, participated in casually or in an organised way for non-commercial or business/commercial reasons that necessitate travel away from home and work locality' (Standeven \& De Knop, 1999, p. 12; see also Weed, 2006); or adventure tourism defined as bringing 'together travel, sport, and outdoor recreation' (Beedie \& Hudson, 2003, p. 626). It is recognised that the analysis of sports tourism expenditure, which is central to local stakeholders in terms of its economic impact (Perić et al., 2019) is primarily based on research related to sports events, with little attention focused on the recreational context (Downward et al., 2009; Drakakis \& Papadaskalopoulos, 2014). Yet, same-day tourism connected with outdoor recreation contributed $£ 2,550$ million to the economy in 2017 in England (Visit England, 2018). Moreover, activity sports tourism during outdoor recreation is also now viewed as a central component of current UK health and well-being policy extending the policy focus from traditional sports (HM Government, 2015; Sport England, 2015, 2016; Sport \& Recreation Alliance, 2017). This suggests that further analysis of the links between trip expenditures and duration, destinations, and activity sports tourism is required to help to inform planning (Andkjær \& Arvidsen, 2015; Chang \& Gibson, 2011; Home et al., 2012). The current paper provides some analysis to help to address this gap, focussing on same-day visits which, according to the Tourism Society, involve visitors spending 'at least 3 hours away from home outside their usual environment for general leisure, recreational and social purposes. Many are local residents of an area' (Middleton, 2015, para. 4). This is as opposed to leisure-day visitors

26 who spend less than three hours away from home. 

well as reviews empirical literature. Key methodological shortcomings of the latter are noted.

3 The data and empirical approach adopted in the research are then presented as a methodological improvement on the literature. The results are presented and then discussed, with tentative implications drawn for policy before conclusions and limitations are offered.

\section{Literature review}

\section{Expenditure and duration: a theoretical foundation}

The theoretical analysis of tourism trips and related activities can be understood from the perspective of the economic theory of demand and, because the experiential and service elements of tourism are intangible, tourism demand is often measured through expenditures (Downward \& Lumsdon, 2000, 2003). As Brida and Scuderi (2013) and Lumsdon et al. (2004) argue, tourism expenditure can be understood as an outcome of household production,

14 drawing on Becker (1965). Crucially, this approach assumes that individuals within

15 households choose to produce commodities for consumption. Inputs to the production are goods purchased by the household through monetary expenditures, but also the time invested by household members in production. Tourism can be considered to imply such choices (Boztug et al., 2015; Downward et al., 2009), because the individual must take multiple decisions on the activities and other aspects that are combined to produce the tourism experience. The latter include the type and length of the trip, the destination, transport mode and so on, which are then naturally linked to expenditures (Grigolon et al., 2014; Wu et al., 2013). The time allocation approach consequently suggests that the two interrelated aspects

23 of expenditure upon, and the duration of, the trip are of simultaneous relevance and thus

24 should be jointly examined in research. 


\section{Expenditure and duration: empirical literature}

Despite these theoretical foundations, however, the empirical literature exploring tourism demand typically, does not model both the expenditure and time involved simultaneously. While there are studies that focus on the factors that drive expenditure only (Alegre et al., 2013; Bernini \& Cracolici, 2015; Boman et al., 2013; Brida \& Scuderi, 2013; Eugenio-Martin \& Inchausti-Sintes, 2016; Lee, 2001; Rashidi \& Koo, 2016; Wu et al., 2013), other studies only focus on the factors that influence the duration of trips (Alén et al., 2014; Grigolon et al., 2014; Vaara \& Matero, 2011; Wynen, 2013a).

Some research has explored the relationship between expenditure and duration, in three limited ways. The first examines expenditure and explores how the duration of trips may influence it but not if expenditure influences duration (Abbruzzo et al., 2014; Akca et al., 2016; Buning et al., 2016; Disegna \& Osti, 2016; Downward \& Lumsdon, 2000, 2003, 2004; Engström \& Kipperberg, 2015; Fredman, 2008; Gholipour et al., 2019; Leones et al., 1998; Lew \& Ng, 2012; Marrocu et al., 2015; Mehmetoglu, 2007; Pouta et al., 2006; Saayman \& Saayman, 2014; Thrane, 2015a; Wynen, 2013b). The second analyses the duration of trips and explores the influence of expenditure on the trip's duration but not the influence of duration on expenditure (Alegre \& Pou, 2006; Barros \& Machado, 2010; Santos et al., 2015). Finally, some research focusses on both expenditure and trip duration, but does not formally account for their simultaneity. Whilst Downward and Lumsdon (2000) and Wynen (2013b) imply expenditure and duration are associated, they do not estimate the simultaneous relationships involved leaving their estimates biased. Likewise, Dane et al. (2014) only assume but do not test the nature of the simultaneity through structural equation modelling.

In general, the previous research finds that expenditure and duration are influenced by factors such as trip characteristics (Alén et al., 2014; Downward et al., 2009) and income 
1 (Alegre et al., 2013; Bernini \& Cracolici, 2015; Boman et al., 2013; Rashidi \& Koo, 2016;

$2 \mathrm{Wu}$ et al., 2013). The effects of socio-demographic status, however, are shown to vary with

3 the type and context of tourism. For example, Akca et al. (2016) find that younger less

4 educated tourists spend more on cave tourism, but Bernini and Cracolici (2015) find that

5 older more educated tourists spend more in Northern Italy and take longer same-day tourism

6 trips in Belgium (Wynen, 2013a). Greater visiting group size is also typically associated with

7 greater expenditures (Downward \& Lumsdon, 2000, 2003, 2004; Eugenio-Martin \&

8 Inchausti-Sintes, 2016). However, the effects of family composition of visitors on demand

9 are found to be mixed (Alegre et al., 2013). Importantly, when the relationship between trip

10 duration and trip expenditures is investigated, a positive relationship is generally found

11 (Aguiló et al., 2017).

The above literature focusses on longer duration tourism. There are some studies that examine same-day visits in the tourism literature. For example, Boman et al. (2013) investigate expenditures associated with outdoor visits taking place close to home in Sweden identifying that such trips accounted for, on average, SEK 10,820 per year; Wynen (2013b) investigates the expenditure associated with same-day visits in Belgium, identifying that expenditures varied, depending on the month, between $€ 42.16$ and $€ 68.97$ per trip on average; Downward and Lumsdon (2000) examine expenditures on same-day visits to the South West of England reporting no average expenditures.

$$
\text { However, these studies do not investigate the reciprocal effect of the role of }
$$

21 expenditure in determining the duration of stay. In contrast this is undertaken by Dane et al.

22 (2014) who examine the expenditure upon, and the duration of, out-of-home leisure activities in the Netherlands. This study also explores different types of activities including: "Outside recreation", "Wellness and beauty", “Attraction visits", "Event visits”, “Culture”, and "Going out". They identify that average expenditures across these activities was $€ 10$ and their 
1 average duration was 3 hours and 21 minutes. Lovelock et al. (2019) also examine different

2 types of outdoor activity in analysing the frequency of participation in them as well as

3 expenditures on them. The activities investigated are: "Hunter", “Angler", "Mountaineer"

4 and "Tramper". No descriptive insight into expenditures and frequency of participation are

5 provided.

6 Finally, some literature focusses on specific sports tourism activities such as diving, -

7 though no descriptive data on expenditures is provided (Saayman \& Saayman, 2014), or

8 cycling in which average total expenditures for trips across certain geographical areas range

9 between $\$ 275.13$ and $\$ 413.76$ in the United States (Buning et al., 2016) or £212 expenditure

10 per group per trip in the UK (Downward et al., 2009). This last study is the only one of these

11 that also explores the influence of duration on expenditure. The typical duration of a groups'

12 trip was 22 hours.

This paper contributes to closing gaps in this literature by making several

contributions. For the first time, it explores the simultaneous relationship between

expenditure and trip duration in same-day visits across England as a whole. It also recognises that tourism expenditure should be analysed in the context of multi-activity trips rather than just linking a specific activity to a trip (Drakakis \& Papadaskalopoulos, 2014). Consequently, rather than focussing on one activity, the analysis also explores the role of different forms of activity sports tourism alongside other tourism activities as contributors to overall same-day tourism expenditure, and the duration of trips. The influence of the type of destination is also accounted for as locations also affect tourism expenditure (Perić et al., 2019).

Methods

\section{Data source}

The data on the same-day visits are drawn from The Monitor of Engagement with the 
1 population, aged 16 years old or older, through an annual rolling cross-section of

2 approximately 45,000 individuals. Data have been collected since 2009 and interviews take

3 place every week with one interview being undertaken per household. The data analysed in

4 the current research represent a subsample of 5,004 individuals covering the period between

52012 to 2016 . This subsample is identified because, since 2012, the duration of trips was only

6 measured for a random sample of visits, and expenditure during these visits is subsequently

7 only asked once during the last week of each month. Consequently, this paper focusses upon

8 the one randomly selected visit in which expenditure data are available and for which visits

9 are of a duration of at least three hours in accordance with the definition of same-day visits.

\section{Variable descriptions}

Two dependent variables are identified. The first is the real total expenditure during

12 the visit "TotalexpR" (in pence). Real values were calculated using the relevant years'

13 Consumer Price Index. The second dependent variable is the total visit duration "Totalhrs"

14 (in hours) for same-day trips of at least three hours' duration.

The independent variables included in the analysis are informed by the literature on activity sport tourism (e.g. Downward et al., 2009) as well as tourism generally (Brida \& Scuderi, 2013) as integral to the analysis of tourism expenditure. The first set of variables are associated with trip characteristics. Activity sports tourism is grouped into walking; cycling and running - as two distinct categories of land-based activities - swimming and water sports - as a category of water-based sports tourism activities - and field sports measuring hunting, fishing, horse-riding and wildlife watching (Lumsdon, 2000; Leung et al., 2008; Mundet \& Coenders, 2010). Off-road driving is also included as a separate activity. The other trip characteristics include more general same-day visit activities such as 24 visits to a beach, or more generic ones, which are either linked primarily to expenditures or the enjoyment of group activity time and these include eating and drinking out, visiting an 
1 attraction and playing with children respectively. The remaining trip characteristic reflects the

2 general tourism activity of scenic driving (Pickering \& Hill, 2007). Finally, a variable

3 measuring the total distance to and from the trip is included.

5 include different aspects of coastal locations and the countryside (both as compared to being

6 in a town). The other groups of correlates identified as important in the literature above

7 include economic constraints, socio-demographic factors and psychographic factors.

8 Variables measuring the employment status, social class, and house ownership of individuals

9 control for the economic constraints on behaviour. In addition, variables measuring age,

10 gender, ethnicity, marital status, and the numbers of adults and the presence of children in the

11 household are included to control for socio-demographic factors. The number of adults and

12 children in the visiting group are also included as group size has been identified to be

13 important in determining expenditure generally and in same-day visits in England in

14 particular (Downward \& Lumsdon, 2000). To account for the motivation for the trip and

15 psychological influences upon behaviour, such as habits and disposition towards taking same-

16 day trips, a variable that measures if the individual had a trip away from home at least once a

17 week in the last 12 months is also included, along with the survey year, which measures the

18 trend in behaviour. Descriptions of the variables and descriptive statistics are included in

19 Table 1.

$<<$ TABLE 1 NEAR HERE $>>$

Methods: three-stage least squares regression

The theoretical discussion outlined above provide a strong indication that both the

23 duration of visits and the expenditures upon them are jointly determined as part of the

24 tourism decision. The aim in the analysis, therefore, is to control for the endogeneity between the two dependent variables; that is, their simultaneous determination, whilst investigating 
1 the impact of activity sports tourism and other tourism activities on each of them. As emphasised by Thrane (2015b) and Eugenio-Martin and Inchausti-Sintes (2016), instrumental variable (IV) estimation is needed to provide robust results if components of demand are simultaneously determined. Consequently, the three-stage least squares (3SLS) estimator is adopted to identify the causal relationships between expenditure and duration. 3SLS is a combination of seemingly unrelated regression (SUR) that accounts for efficient estimation of equations in which there is potential correlation across the errors, and two-stage least squares (2SLS), in which IVs identify the causal relationships (Zellner \& Theil, 1962). The core model is given in Equation 1:

In this model, for $i$ individuals over $t$ time periods, the dependent variables

'TotalexpR', and 'Totalhrs', are jointly regressed on each other - as simultaneity is assumed and on "j" trip characteristic variables "TC", "k" location variables "L", "l” sociodemographic characteristics of the individuals "SD", "m" variables capturing the individuals" economic status " $E$ ", and " $n$ " variables measuring their motivation and habit "M". " $\mu$ " is a random error having a normal distribution, mean value of zero and constant variance as in ordinary least squares (OLS). As different sets of variables enter each equation there are gains in efficiency compared to OLS estimation of each equation separately (Wooldridge, 2010). Moreover, as correlation between the random errors is accounted for, this helps to control for endogeneity associated with unobserved heterogeneity between the behaviours. 
1 This might be due to, for example, different dispositions to be active, or avoid too much travel and to be self-sufficient regarding hospitality, etc. influences, IVs are used. Valid IVs are exogenous variables that are linked to both the expenditure and duration dependent variables and uncorrelated with the errors in each of their equations. Eight region of trip origin dummy variables, excluding London as the base category, are used as IVs under the theoretical assumption that the place of origin of the trip will constrain the supply-side opportunities of feasible same-day trips.

which capture how components of the trip directly affects expenditure and duration, and the effects that each of these behaviours have on one another, the parameters can be understood as initial direct effects. Additional impacts may take place, however, because if, for example, one of the factors that affects expenditure changes, there will be indirect effects on expenditure if this factor also affects duration. This is because the impact on duration will also impact on expenditure and this interrelationship will iterate. The same process will apply to changes in the factors that affect duration. To identify the total effects Equation 2 is needed, which is the reduced form of Equation 1:

$$
\begin{aligned}
\text { TotalexpR } & \mathrm{A}_{1}+\sum \frac{\left(\beta_{\mathrm{j}}+\delta_{\mathrm{j}} \alpha_{2}\right)}{\left(1-\alpha_{2} \gamma_{2}\right)} \mathrm{TC}_{\mathrm{it}}+\Sigma \frac{\left(\beta_{\mathrm{k}}+\delta_{\mathrm{k}} \alpha_{2}\right)}{\left(1-\alpha_{2} \gamma_{2}\right)} \mathrm{L}_{\mathrm{it}}+\Sigma \frac{\left(\beta_{1}+\delta_{1} \alpha_{2}\right)}{\left(1-\alpha_{2} \gamma_{2}\right)} \mathrm{SD}_{\mathrm{it}} \\
& +\Sigma \frac{\left(\beta_{\mathrm{m}}+\delta_{\mathrm{m}} \alpha_{2}\right)}{\left(1-\alpha_{2} \gamma_{2}\right)} \mathrm{E}_{\mathrm{it}}+\Sigma \frac{\left(\beta_{\mathrm{n}}+\delta_{\mathrm{n}} \alpha_{2}\right)}{\left(1-\alpha_{2} \gamma_{2}\right)} \mathrm{M}_{\mathrm{it}}+\Omega_{1 \mathrm{it}}
\end{aligned}
$$

$$
\begin{aligned}
\text { Totalhrs }_{\mathrm{it}}=\mathrm{C}_{1} & +\Sigma \frac{\left(\delta_{\mathrm{j}}+\beta_{\mathrm{j}} \gamma_{2}\right)}{\left(1-\alpha_{2} \gamma_{2}\right)} \mathrm{TC}_{\mathrm{it}}+\Sigma \frac{\left(\delta_{\mathrm{k}}+\beta_{\mathrm{k}} \gamma_{2}\right)}{\left(1-\alpha_{2} \gamma_{2}\right)} \mathrm{L}_{\mathrm{it}}+\Sigma \frac{\left(\delta_{1}+\beta_{1} \gamma_{2}\right)}{\left(1-\alpha_{2} \gamma_{2}\right)} \mathrm{SD}_{\mathrm{it}} \\
& +\Sigma \frac{\left(\delta_{\mathrm{m}}+\beta_{\mathrm{m}} \gamma_{2}\right)}{\left(1-\alpha_{2} \gamma_{2}\right)} \mathrm{E}_{\mathrm{it}}+\Sigma \frac{\left(\delta_{\mathrm{n}}+\beta_{\mathrm{n}} \gamma_{2}\right)}{\left(1-\alpha_{2} \gamma_{2}\right)} \mathrm{M}_{\mathrm{it}}+\Omega_{2 \mathrm{it}}
\end{aligned}
$$



simultaneity has been accounted for. The parameters associated with these equations are composite values derived from the structural parameters in Equation 1. The interpretation of the parameters in Equation 2 can be exemplified with reference to, for example, the coefficients measuring 'TC' on 'TotalexpR'. 'TC' here could refer to one of the ' $\mathrm{j}$ ' sports tourism activities. The first component in the numerator then is the direct effect of this particular ' $\mathrm{j}$ ' 'TC' on expenditure. The second component of the numerator measures the direct effect of the change in the same ' $\mathrm{TC}$ ' on the duration of the trip, multiplied by the effect of the duration of the trip on expenditure. This identifies an indirect effect of how the characteristic affects expenditure because the duration of the trip has also changed because of the change in a sports tourism activity i.e. a component of ' $\mathrm{TC}$ '. The denominator of the expression is a multiplier term that captures the impact of the flow of the combined direct and indirect effects through the system as expenditure and duration interact. The composite parameter thus measures the total effect of an independent variable on either expenditure or 15 duration.

\section{Results}

Instrumental variables: relevance and validity

The relevance of the IVs was assessed and confirmed by estimating Equation 2 as a SUR model, including the relevant region of origin IVs, and then jointly testing for the significance of the latter (Baum et al., 2003). The joint test is large enough to reject the null hypothesis of no joint significance at the $5 \%$ level for the system of equations $\left(\chi^{2}(16)=\right.$ $28.84)$. Secondly, the validity of the IVs can be inferred from a Hansen-Sargan test $\left(\chi^{2}(13)=\right.$ 10.339), derived from estimating Equation 1. These imply accepting the null hypothesis of no 
1 correlation, at the 5\% level, between the IVs and the error terms of Equation 1 (Baum et al., 2 2003).

\section{Expenditure and duration}

Table 2 reports the results based on the 3SLS regression. $<<$ TABLE 2 NEAR HERE $>>$

The coefficients for each specific variable in the columns headed "Direct Effect" are estimates of the structural parameters from Equation 1 and they capture the direct impact of the independent variables on expenditures and duration, respectively. If a parameter is significant in both equations, the "Total Effect" is also reported based on Equation 2. If the parameter is only significant in Equation 1 the total effect collapses into the direct effect.

\section{Overall methodological and theoretical insights}

Before exploring the impact of activity sports tourism on expenditure and duration, and recognising the desire to offer methodological improvement to the literature, initial overview of the results in Table 2 suggests that, in line with the literature discussed above, total expenditure and the duration of the trip are positively related as each variable is significant in the regression of the other (consistent with, for example, Downward et al., 2009). However, the direct effects results show that focussing on a specific aspect of a trip e.g. the sports tourism activity of walking, an increase in expenditure is associated with a direct reduction in the duration of the trip and vice versa. This pattern of opposite signs is the case for all the activities. It shows that for a given level of expenditure and duration (as each of these are controlled for in the analysis of the other through Equation 1), individuals have to substitute the inputs to their trip such that an increase in one input is met by a reduction in the other. This is expected in production theory in economics, which was merged with consumer theory by Becker (1965). This adds validity to the analysis. However, in order to derive the full implications from the analysis, the total effects need to be examined, as described by 
1 Equation 2, which captures the impact of a change in a feature of a trip on either expenditure

2 or duration, allowing the level of duration and expenditure to have changed.

\section{Total effects of activity sports tourism on expenditure and duration}

The total effects show that if the most popular sports tourism activity of walking is present on a trip, it reduces expenditure by $£ 0.88$ on average compared to trips that do not include walking. Moreover, trips that include walking are 18 minutes less in duration on average compared to those that do not include walking. There are no effects of the presence of cycling or running, and swimming or water sports, on either expenditure or duration.

However, if field activities are present on a trip, expenditures are $£ 1.89$ higher on average and trips are approximately 43 minutes longer on average than if they are not present. Scenic driving, as a general tourism activity increases expenditure by approximately $£ 0.29$ but trips are approximately 41 minutes shorter on average. These results indicate that the relative impact of activity sports tourism is greater on trip durations rather than expenditures.

The estimates also identify that the main drivers of expenditure are hospitality and attractions, which add approximately $£ 13.27$ and $£ 12.56$ respectively on average if they are present on a trip and these also increase the duration of trips by approximately 10 minutes and 7 minutes on average respectively. Such positive results suggest that unlike activity sports tourism, these other activities contribute relatively more to expenditure than duration. The results are consistent with the previous literature that explores expenditure in the sameday context (Boman et al., 2013; Wynen, 2013b) and the previous work that explores the direct relationship between expenditure and duration of trips (Downward et al., 2009).

Overall, the results suggest that across the portfolio of trip characteristics, that include activity sports tourism and other activities, relatively greater expenditures on trips are balanced by relatively lower contributions to the duration of a trip and vice versa. The trade offs between the direct effects of specific activities is to an extent preserved when 
1 considering the relative size of the overall changes in expenditure and duration across all the 2 activities undertaken.

The analysis also reveals that visits to the countryside are characterised by approximately $£ 4.63$ less expenditure and lower duration of just over a minute relative to other locations outside of urban green space. The results also show that there is a direct positive impact of the distance travelled on the duration of a same-day visit. Distance is a measure of proximity and partly captures accessibility to outdoor opportunities (Kim \& Nicholls, 2016). However, there is no impact on expenditure. Finally, the remaining results in Table 2 are related to the impact of individual economic, socio-demographic and psychographic factors and overall the results are in line with previous literature.

The causal results show that the key activities that primarily drive expenditures on same-day activity tourism across England are attractions and hospitality. These are, hence, important sources of direct economic impact. However, the results also suggest that as part of trip portfolios the most ubiquitous sports tourism activity of walking marginally reduces that impact, whilst field sports can contribute to it but in a relatively small way. Moreover, both other land and water-based activity sports tourism do not contribute either to expenditures or duration. This suggests that from the perspective of increasing potential economic impact, activity sports tourism needs to be better integrated into an overall tourism product in a specific location (Hallmann et al., 2012). market can be managed simultaneously within the confines of, say, a specific outdoor trail, and despite there being different motivations for visiting (Spencer, 2012). Therefore, 
1 relationships ("horizontal links") that exists within the activity sports tourism sector and with

2 other tourism activity sectors ("vertical links") (Langenbach \& Tuppen, 2017). One

3 particular challenge here reflects rural locations in which activity sports tourism may often

4 take place. As the results show, countryside locations exhibit less expenditure compared to

5 urban ones, and this might be because isolation is desired by visitors (Lane \& Kastenholz,

6 2015). It remains, however, that the identification of "centres of gravity" of activity - from

7 where visits start and finish - in such locations may provide opportunities for investment in

8 the infrastructure that can yield expenditures (Lumsdon et al., 2004) providing the attraction

9 is sufficiently strong (Prideaux, 2002).

10 The results are also suggestive of potential health and well-being impacts from

11 activity sports tourism. Although the duration and intensity of the sports tourism activities that could contribute to meeting recommended health guidelines is not directly measured in the current research, it is recognised that some exercise is better than none as a contribution to health (WHO, 2020) and, moreover that simply being in, or exercising in the outdoors contributes to personal well-being (MacKerron \& Mourato, 2013). The above results thus suggest that there is evidence of a potential trade-off between meeting these policy aspirations through activity sport tourism and economic impact. Seeking to leverage further expenditure from these activities, for example in rural locations, may thus add positive economic outcomes to the likely health and well-being outcomes being obtained. Greater strategic alignment between public health and activity sports tourism would be required to contribute to both the development of the local economy and to achieving a healthy and active nation in the UK (Page et al., 2017). 


\section{Conclusion}

2

Drawing upon time allocation theory, and using a unique large-scale dataset, this

4

paper contributes to the literature by exploring the expenditure incurred on, and duration of, same-day tourism across England, exploring the role of activity sports tourism alongside other activities in a trip. Using a 3SLS regression analysis, both direct and total effects of changes in factors affecting expenditures and duration are examined to critically reflect upon the simultaneity between these choices that is neglected in the existing sports tourism literature.

The results identify that the key drivers of expenditure are shown to be visiting attractions and hospitality, whilst the most ubiquitous sports tourism activity of walking reduces expenditures and the duration of trips. Other land and water-based activity sports tourism does not affect expenditure or duration, but field sports do in a small way. This suggests that there is need to facilitate opportunities for expenditure through attractions and hospitality if these activities are to contribute to the economic impact of localities. Visits to the countryside are also shown to reduce expenditures. As this is where much activity sports tourism takes place, this is perhaps most pressing for the rural setting. Nonetheless, it remains that activity sports tourism can contribute to health and well-being through physical activity, and well-being through just being outdoors. It follows that greater coordinated investment in supporting these activities might create both economic and health and well-being outcomes for society.

The above analysis makes it clear that that expenditure and duration behaviour depends on a portfolio of more and less physically active sports tourism activities as well as other activities. Moreover, these will reflect the specific locations chosen, which in turn will be influenced from where trips originate. The current data do not permit more detailed analysis of these portfolios or opportunities in the location of trip origins. This is a limitation 
1 and future research should seek to further explore these spatial linkages and behaviours. This

2 is important because the challenges faced by the more rural locations where activity sports

3 tourism usually occurs (Drakakis \& Papadaskalopoulos, 2014) are likely to require more

4 policy planning and coordination than more urban attractions as there is evidence that many

5 policies aimed at rural areas have not been successful (Lazzarini, 2018). Moreover, clearer

6 insight into the duration and intensity of specific sports tourism activities would help to

7 assess their contribution to health and well-being. The current research can only draw indirect

8 inferences so data that can add these dimensions of activity sports tourism would improve

9 insight.

10

11 Disclosure statement

12 No potential conflict of interest was reported by the authors.

13 
2 Abbruzzo, A., Brida, J. G., \& Scuderi, R. (2014). Determinants of individual tourist expenditure as a network: Empirical findings from Uruguay. Tourism Management, 43, 36-45. https://doi.org/10.1016/j.tourman.2014.01.014

Aguiló, E., Rosselló, J., \& Vila, M. (2017). Length of stay and daily tourist expenditure: A joint analysis. Tourism Management Perspectives, 21, 10-17. https://doi.org/10.1016/j.tmp.2016.10.008

Akca, H., Sayili, M., \& Cafri, R. (2016). Analysing expenditure of same-day visitors in cave tourism: the case of Turkey. Tourism Economics, 22(1), 47-55. https://doi.org/10.5367/te.2014.0413

Alegre, J., Mateo, S., \& Pou, L. (2013). Tourism participation and expenditure by Spanish households: The effects of the economic crisis and unemployment. Tourism Management, 39, 37-49. https://doi.org/10.1016/j.tourman.2013.04.002

Alegre, J., \& Pou, L. (2006). The length of stay in the demand for tourism. Tourism Management, 27(6), 1343-1355. https://doi.org/10.1016/j.tourman.2005.06.012

Alén, E., Nicolau, J. L., Losada, N., \& Domínguez, T. (2014). Determinant factors of senior tourists' length of stay. Annals of Tourism Research, 49, 19-32. https://doi.org/10.1016/j.annals.2014.08.002

Andkjær, S., \& Arvidsen, J. (2015). Places for active outdoor recreation-a scoping review. Journal of Outdoor Recreation and Tourism, 12, 25-46. https://doi.org/10.1016/j.jort.2015.10.001

Barros, C. P., \& Machado, L. P. (2010). The length of stay in tourism. Annals of Tourism Research, 37(3), 692-706. https://doi.org/10.1016/j.annals.2009.12.005 
1 Baum, C. F., Schaffer, M. E., \& Stillman, S. (2003). Instrumental variables and GMM: Estimation and testing. STATA Journal, 3(1), 1-31. https://doi.org/10.1177/1536867X0300300101

Becker, G. S. (1965). A Theory of the Allocation of Time. The Economic Journal, 75(299) 493-517. https://doi.org/10.2307/2228949

Beedie, P., \& Hudson, S. (2003). Emergence of mountain-based adventure tourism. Annals of Tourism Research, 30(3), 625-643. https://doi.org/10.1016/S0160-7383(03)00043-4

Bernini, C., \& Cracolici, M. F. (2015). Demographic Change, Tourism Expenditure and Life Cycle Behaviour. Tourism Management, 47, 191-205.

Boman, M., Fredman, P., Lundmark, L., \& Ericsson, G. (2013). Outdoor recreation-a necessity or a luxury? Estimation of Engel curves for Sweden. Journal of Outdoor Recreation and Tourism, 3-4, 49-56. https://doi.org/10.1016/j.tourman.2014.09.016

Boztug, Y., Babakhani, N., Laesser, C., \& Dolnicar, S. (2015). The hybrid tourist. Annals of Tourism Research, 54, 190-203. https://doi.org/10.1016/j.annals.2015.07.006

Brida, J. G., \& Scuderi, R. (2013). Determinants of Tourist Expenditure: A Review of Microeconomic Models. Tourism Management Perspectives, 6, 28-40. https://doi.org/10.2139/ssrn.2048221

Buning, R. J., Cole, Z. D., \& McNamee, J. B. (2016). Visitor expenditure within a mountain bike event portfolio: Determinants, outcomes, and variations. Journal of Sport \& Tourism, 20(2), 103-122. https://doi.org/10.1080/14775085.2016.1239547

Chang, S., \& Gibson, H. J. (2011). Physically active leisure and tourism connection: Leisure involvement and choice of tourism activities among paddlers. Leisure Sciences, 33(2), 162-181. https://doi.org/10.1080/01490400.2011.550233

Dane, G., Arentze, T. A., Timmermans, H. J., \& Ettema, D. (2014). Simultaneous modelling of individuals' duration and expenditure decisions in out-of-home leisure activities. 

https://doi.org/10.1016/j.tra.2014.10.003

3 Disegna, M., \& Osti, L. (2016). Tourists' expenditure behaviour: the influence of satisfaction and the dependence of spending categories. Tourism Economics, 22(1), 5-30. https://doi.org/10.5367/te.2014.0410

Downward, P., \& Lumsdon, L. (2000). The demand for day-visits: an analysis of visitor spending. Tourism Economics, 6(3), 251-261. https://doi.org/10.5367/000000000101297622

Downward, P., \& Lumsdon, L. (2003). Beyond the demand for day-visits: an analysis of visitor spending. Tourism Economics, 9(1), 67-76. https://doi.org/10.5367/000000003101298277

Downward, P., \& Lumsdon, L. (2004). Tourism transport and visitor spending: a study in the North York Moors National Park, UK. Journal of Travel Research, 42(4), 415-420. https://doi.org/10.1177/0047287504263038

Downward, P., Lumsdon, L., \& Weston, R. (2009). Visitor expenditure: the case of cycle recreation and tourism. Journal of Sport \& Tourism, 14(1), 25-42. https://doi.org/10.1080/14775080902847397

Drakakis, P., \& Papadaskalopoulos, A. (2014). Economic contribution of active sport tourism: The case of four sport activities in Messinia, Greece. Journal of Sport \& Tourism, 19(3-4), 199-231. https://doi.org/10.1080/14775085.2015.1070740

Engström, T., \& Kipperberg, G. (2015). Decomposing the heterogeneous discretionary spending of international visitors to Fjord Norway. Tourism Management, 51, 131141. https://doi.org/10.1016/j.tourman.2015.05.020 
1 Eugenio-Martin, J.L., \& Inchausti-Sintes, F. (2016). Low-cost travel and tourism expenditures. Annals of Tourism Research, 57, 140-159. https://doi.org/10.1016/j.annals.2015.11.019

Fredman, P. (2008). Determinants of visitor expenditures in mountain tourism. Tourism Economics, 14(2), 297-311. https://doi.org/10.5367/000000008784460418

Gholipour, H. F., Min, L. W. L., Ling, L. A., \& Jopp, R. (2019). Environmentally friendly tourists and spending on nature-based activities. Journal of Ecotourism, 18(2), 174180. https://doi.org/10.1080/14724049.2018.1498505

Grigolon, A. B., Borgers, A. W., Kemperman, A. D., \& Timmermans, H. J. (2014). Vacation length choice: A dynamic mixed multinomial logit model. Tourism Management, 41, 158-167. https://doi.org/10.1016/j.tourman.2013.09.002

Hallmann, K., Feiler, S., Müller, S., \& Breuer, C. (2012). The interrelationship between sport activities and the perceived winter sport experience. Journal of Sport \& Tourism, 17(2), 145-163. https://doi.org/10.1080/14775085.2012.729905

HM Government. (2015). Sporting Future: A New Strategy for an Active Nation.

Department for Digital, Culture, Media \& Sport and Tracey Crouch MP.

Home, R., Hunziker, M., \& Bauer, N. (2012). Psychosocial outcomes as motivations for visiting nearby urban green spaces. Leisure Sciences, 34(4), 350-365. https://doi.org/10.1080/01490400.2012.687644

Kim, J., \& Nicholls, S. (2016). Influence of the measurement of distance on assessment of recreation access. Leisure Sciences, 38(2), 118-139. https://doi.org/10.1080/01490400.2015.1071211

Lane, B., \& Kastenholz, E. (2015). Rural tourism: the evolution of practice and research approaches - towards a new generation concept? Journal of Sustainable Tourism, 23(8-9), 1133-1156. https://doi.org/10.1080/09669582.2015.1083997 
1 Langenbach, M., \& Tuppen, J. (2017). The concept of localised outdoor sports tourist systems: its application to Ardèche in south-east France. Journal of Sport \& Tourism, 21(4), 263-286. https://doi.org/10.1080/14775085.2017.1351388

Lazzarini, L. (2018). The role of planning in shaping better urban-rural relationships in Bristol City Region. Land Use Policy, 71, 311-319. https://doi.org/10.1016/j.landusepol.2017.12.005

Lee, H. C. (2001). Determinants of recreational boater expenditures on trips. Tourism Management, 22(6), 659-667. https://doi.org/10.1016/S0261-5177(01)00033-4

Leones, J., Colby, B., \& Crandall, K. (1998). Tracking expenditures of the elusive nature

Lumsdon, L. (2000). Transport and tourism: cycle tourism-a model for sustainable tourists of Southeastern Arizona. Journal of Travel Research, 36(3), 56-64. https://doi.org/10.1177/004728759803600306

Leung, Y. F., Marion, J. L., \& Farrell, T. A. (2008). Recreation ecology in sustainable tourism and ecotourism; A strengthening role. McCool and Moisey (Eds.). Tourism Recreation and Sustainability, 19-37. https://doi.org/10.1079/9781845934705.0019

Lew, A. A., \& Ng, P. T. (2012). Using quantile regression to understand visitor spending. Journal of Travel Research, 51(3), 278-288. https://doi.org/10.1177/0047287511410319

Lovelock, B., Jellum, C., Carr, A., \& Jowett, T. (2019). An exploration of commitment in nature-based recreation, and its relationship with participation and purchase behaviour. Annals of Leisure Research, 22(3), 373-394. https://doi.org/10.1080/11745398.2018.1537853 development?. Journal of Sustainable Tourism, 8(5), 361-377. https://doi.org/10.1080/09669580008667373 
1 Lumsdon, L., Downward, P., \& Cope, A. (2004). Monitoring of cycle tourism on long distance trails: The North Sea Cycle Route. Journal of Transport Geography, 12(1). https://doi.org/10.1016/j.jtrangeo.2003.10.007

MacKerron, G., \& Mourato, S. (2013). Happiness is greater in natural environments. Global Environmental Change, 23(5), 992-1000. https://doi.org/10.1016/j.gloenvcha.2013.03.010

Marrocu, E., Paci, R., \& Zara, A. (2015). Micro-economic determinants of tourist expenditure: A quantile regression approach. Tourism Management, 50, 13-30. https://doi.org/10.1016/j.tourman.2015.01.006

Mehmetoglu, M. (2007). Nature-based tourists: The relationship between their trip expenditures and activities. Journal of Sustainable Tourism, 15(2), 200-215. https://doi.org/10.2167/jost642.0

Middleton, V. (2015). Tourism Definitions. The Tourism Society. http://www.tourismsociety.org/page/88/tourism-definitions.htm

Mundet, L., \& Coenders, G. (2010). Greenways: a sustainable leisure experience concept for both communities and tourists. Journal of Sustainable Tourism, 18(5), 657-674. https://doi.org/10.1080/09669581003668524

Natural England (2013). Monitor of Engagement with the Natural Environment: The national survey on people and the natural environment: Technical Report from the 2012 2013 survey, Natural England Commissioned Report NECR122.

Page, S. J., Hartwell, H., Johns, N., Fyall, A., Ladkin, A., \& Hemingway, A. (2017). Case study: Wellness, tourism and small business development in a UK coastal resort: Public engagement in practice. Tourism Management, 60, 466-477. https://doi.org/10.1016/j.tourman.2016.12.014 
1 Perić, M., Dragičević, D., \& Škorić, S. (2019). Determinants of active sport event tourists' expenditure-the case of mountain bikers and trail runners. Journal of Sport \& Tourism, 23(1), 19-39. https://doi.org/10.1080/14775085.2019.1623064

Pickering, C. M., \& Hill, W. (2007). Impacts of recreation and tourism on plant biodiversity and vegetation in protected areas in Australia. Journal of Environmental Management, 85(4), 791-800. https://doi.org/10.1016/j.jenvman.2006.11.021

Pouta, E., Neuvonen, M., \& Sievänen, T. (2006). Determinants of nature trip expenditures in Southern Finland-implications for nature tourism development. Scandinavian Journal of Hospitality and Tourism, 6(2), 118-135. https://doi.org/10.1080/15022250600658937

Prideaux, B. (2002). Building visitor attractions in peripheral areas? Can uniqueness overcome isolation to produce viability? International Journal of Tourism Research, 4(5), 379-389. https://doi.org/10.1002/jtr.387

Rashidi, H.T., \& Koo T.T.R. (2016). An analysis on travel party composition and expenditure: A discrete-continuous model. Annals of Tourism Research, 56, 48 - 64. https://doi.org/10.1016/j.annals.2015.10.003

Saayman, M., \& Saayman, A. (2014). How deep are scuba divers' pockets?. Tourism Economics, 20(4), 813-829. https://doi.org/10.5367/te.2013.0299

Santos, G. E. d. O., Ramos, V., \& Rey-Maquieira, J. (2015). Length of Stay at Multiple Destinations of Tourism Trips in Brazil. Journal of Travel Research, 54(6), 788-800. https://doi.org/10.1177/0047287514532370

Sato, S., Gipson, C., Todd, S., \& Harada, M. (2018). The relationship between sport tourists' perceived value and destination loyalty: an experience-use history segmentation approach. Journal of Sport \& Tourism, 22(2), 173-186. https://doi.org/10.1080/14775085.2017.1348967 
1 Spencer, D. M. (2012). Understanding recreation activity participants as clientele groups of multi-use recreation areas. Annals of Leisure Research, 153, 227-242. https://doi.org/10.1080/11745398.2012.716619

Sport and Recreation Alliance (2017). Reconomics Plus. The Economic, Health and Social Value of Outdoor Recreation. https://sramedia.s3.amazonaws.com/media/documents/699fec08-3f90-4e00-ac4ac074b353a38d.pdf

Sport England (2015). Getting Active Outdoors: A study of Demography, Motivation, Participation and Provision in Outdoor Sport and Recreation in England.

Sport England (2016). The National Picture. https://www.sportengland.org/research/whoplays-sport/national-picture/

Standeven, J., \& De Knop, P. (1999). Sport Tourism. Human Kinetics.

Thrane, C. (2015a). Students' summer tourism: an econometric analysis of trip costs and trip expenditures. Tourism Management Perspectives, 15, 65-71. https://doi.org/10.1016/j.tmp.2015.03.012

Thrane, C. (2015b). On the relationship between length of stay and total trip expenditures: a case study of instrumental variable (IV) regression analysis. Tourism Economics, 21(2), 357-367. https://doi.org/10.5367/te.2014.0357

Vaara, M., \& Matero, J. (2011). Modeling daily outdoor recreation participation and time-use as a two-stage choice process: a Finnish example. Leisure Sciences, 33(4), 269-289. https://doi.org/10.1080/01490400.2011.582820

Visit England (2018). The Great Britain Day Visitor 2017 Annual Report. https://www.visitbritain.org/sites/default/files/vb-corporate/DocumentsLibrary/documents/England-documents/260139488_-_kantar_tns__gbdvs_2017_annual_report_v5r.pdf 
1 Weed, M. (2006). Sports tourism research 2000-2004: A systematic review of knowledge and a meta-evaluation of methods. Journal of Sport and Tourism, 11(1), 5-30. https://doi.org/10.1080/14775080600985150

Whitehead, J. C., \& Wicker, P. (2018). Estimating willingness to pay for a cycling event using a willingness to travel approach. Tourism Management, 65, 160-169. https://doi.org/10.1016/j.tourman.2017.09.023 Zellner, A., \& Theil, H. (1962). Three stage least squares: Simultaneous estimate of simultaneous equations. Econometrica, 29, 54-78. https://doi.org/10.2307/1911287 and adolescents, adults and older adults. March, 1-34. https://www.who.int/docs/default-source/physical-activity/call-for-consultation/draftguideline-on-physical-activity-and-sedentray-behaviour.pdf?sfvrsn=ddf523d5_4

Wooldridge, J. M. (2010). Econometric Analysis of Cross Section and Panel Data. MIT press.

Wu, L., Zhang, J., \& Fujiwara, A. (2013). Tourism participation and expenditure behaviour: Analysis using a scobit based discrete-continuous choice model. Annals of Tourism Research, 40, 1-17. https://doi.org/10.1016/j.annals.2012.09.002

Wynen, J. (2013a). Explaining travel distance during same-day visits. Tourism Management, 36, 133-140. https://doi.org/10.1016/j.tourman.2012.11.007

Wynen, J. (2013b). An estimation of the determinants of same-day visit expenditures in Belgium. Tourism Economics, 19(1), 161-172. https://doi.org/10.5367/te.2013.0190 
Table 1.

Variable Descriptions

\begin{tabular}{|c|c|c|c|}
\hline Variable & Description & $\underline{\text { Mean }}$ & $\underline{\text { Std.Dev }}$ \\
\hline \multicolumn{4}{|l|}{ Dependent } \\
\hline Totalhrs & Duration of trip (hours) & 5.20 & 3.02 \\
\hline TotalexpR & Total real expenditure (pence) & 2156 & 4637 \\
\hline \multicolumn{4}{|l|}{ Trip Characteristics } \\
\hline Distoutback & Total distance travelled out and back (miles) & 35.40 & 51.08 \\
\hline Walk & Trip involved a walk ( $1=$ yes; $0=$ no) & 0.47 & 0.50 \\
\hline Activeland & Trip involved cycling, running $(1=$ yes; $0=$ no $)$ & 0.06 & 0.23 \\
\hline Activewater & Trip involved swimming, water sports $(1=$ yes; $0=$ no $)$ & 0.02 & 0.15 \\
\hline Field & Trip involved shooting, hunting, fishing, horse-riding, wildlife watching $(1=$ yes; $0=$ no) & 0.08 & 0.28 \\
\hline Eat & Trip involved eating or drinking out, picnicking $(1=$ yes; $0=$ no $)$ & 0.28 & 0.45 \\
\hline Attraction & Trip involved visiting an attraction ( $1=$ yes; $0=$ no) & 0.11 & 0.32 \\
\hline Beach & Trip involved visit to a beach, sunbathing or paddling ( $1=$ yes; $0=$ no) & 0.05 & 0.22 \\
\hline Playchild & Trip involved playing with children $(1=$ yes; $0=$ no $)$ & 0.19 & 0.39 \\
\hline Scenic & Trip involved appreciating scenery from a car $(1=y e s ; 0=n o)$ & 0.03 & 0.17 \\
\hline Offroad & Trip involved off-road driving $(1=$ yes; $0=$ no $)$ & 0.004 & 0.06 \\
\hline \multicolumn{4}{|l|}{ Location } \\
\hline Searesort & Main location was a seaside resort or town ( $1=$ yes; $0=$ no) & 0.14 & 0.34 \\
\hline Seacoast & Main location was the seaside coastline, beach and cliffs $(1=y e s ; 0=n o)$ & 0.04 & 0.20 \\
\hline Country & Main location was the countryside ( $1=y e s ; 0=$ no $)$ & 0.38 & 0.49 \\
\hline \multicolumn{4}{|l|}{ Socio-Demographic } \\
\hline Numadults & Number of adults on the trip & 3.16 & 4.84 \\
\hline Numchild & Number of children on the trip & 0.98 & 3.20 \\
\hline Childinhh & Children in the household ( $1=$ yes; $0=$ no) & 0.35 & 0.48 \\
\hline
\end{tabular}




\begin{tabular}{|c|c|c|c|}
\hline Adultsinhh & Number of adults in the household & 2.14 & 0.94 \\
\hline Agemid & Age in years (midpoint) & 44.31 & 16.13 \\
\hline Sex & Sex $(1=$ male; $0=$ female $)$ & 0.51 & 0.50 \\
\hline Marital & Married $(1=$ yes; $0=$ no $)$ & 0.61 & 0.49 \\
\hline Whitebritish & White British $(1=$ yes; $0=$ no $)$ & 0.83 & 0.38 \\
\hline \multicolumn{4}{|l|}{ Economic } \\
\hline Workft & Works full-time $(1=$ yes; $0=$ no $)$ & 0.38 & 0.49 \\
\hline Socialgradeab & Social grade A or B $(1=$ yes; $0=$ no $)$ & 0.23 & 0.42 \\
\hline Ownbuyhouse & Own or buying a house $(1=$ yes; $0=$ no $)$ & 0.59 & 0.49 \\
\hline \multicolumn{4}{|l|}{ Motivation/Habit } \\
\hline Surveyyear & Year of survey: 1 (2012-2013); 2 (2013-2014); 3 (2014-2015); 4 (2015-2016) & 2.54 & 1.10 \\
\hline Triptaste & Had a trip away from home at least once a week in the last 12 months $(1=y e s ; 0=$ no $)$ & 0.78 & 0.42 \\
\hline \multicolumn{4}{|c|}{ 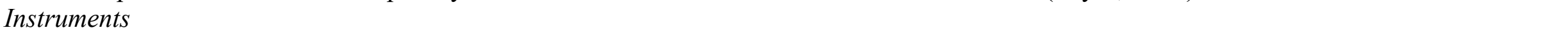 } \\
\hline Emid & East Midlands $(1=$ yes; $0=$ no $)$ & 0.08 & 0.27 \\
\hline East & East $(1=$ yes; $0=$ no $)$ & 0.11 & 0.31 \\
\hline $\mathrm{NE}$ & North East $(1=y e s ; 0=$ no $)$ & 0.06 & 0.24 \\
\hline NW & North West $(1=$ yes; $0=$ no $)$ & 0.13 & 0.33 \\
\hline SE & South East $(1=$ yes; $0=$ no $)$ & 0.16 & 0.37 \\
\hline SW & South West $(1=$ yes; $0=$ no $)$ & 0.14 & 0.35 \\
\hline Wmid & West Midlands $(1=$ yes; $0=$ no $)$ & 0.09 & 0.28 \\
\hline YorkH & Yorkshire and Humberside $(1=$ yes; $0=$ no $)$ & 0.10 & 0.31 \\
\hline
\end{tabular}


Table 2.

3SLS Regression Estimates: Total Expenditure and Total Duration

\begin{tabular}{|c|c|c|c|c|}
\hline Model & (Direct Effect) & (Total Effect) & (Direct Effect) & (Total Effect) \\
\hline Independent & TotalexpR & TotalexpR & Totalhrs & Totalhrs \\
\hline Totalhrs & $\begin{array}{l}1771.8^{* * *} \\
(3.91)\end{array}$ & & $\mathrm{n} / \mathrm{a}$ & \\
\hline TotalexpR & $\mathrm{n} / \mathrm{a}$ & & $\begin{array}{l}0.000488^{* * *} \\
(4.45)\end{array}$ & \\
\hline \multirow[t]{2}{*}{ Distoutback } & -24.31 & & $0.0163^{* *}$ & \\
\hline & $(-1.29)$ & & $(2.17)$ & \\
\hline \multirow[t]{2}{*}{ Surveyyear } & 37.43 & & -0.0326 & \\
\hline & $(0.48)$ & & $(-0.85)$ & \\
\hline \multirow[t]{2}{*}{ Walk } & $439.8^{* *}$ & -88.72 & $-0.255^{* * *}$ & -0.30 \\
\hline & $(2.11)$ & & $(-2.86)$ & \\
\hline \multirow[t]{2}{*}{ Activeland } & 310.2 & & -0.232 & \\
\hline & $(0.77)$ & & $(-1.23)$ & \\
\hline \multirow[t]{2}{*}{ Activewater } & 157.7 & & -0.0381 & \\
\hline & $(0.30)$ & & $(-0.13)$ & \\
\hline \multirow[t]{2}{*}{ Field } & $-1071.2^{* * *}$ & 188.71 & $0.619^{* * *}$ & 0.71 \\
\hline & $(-2.61)$ & & $(4.31)$ & \\
\hline \multirow[t]{2}{*}{ Eat } & $1037.2^{* * *}$ & 1327.18 & $-0.484^{* * *}$ & 0.16 \\
\hline & $(5.60)$ & & $(-2.77)$ & \\
\hline \multirow[t]{2}{*}{ Attraction } & $1045.3^{* * *}$ & 1256.12 & $-0.494^{* *}$ & 0.12 \\
\hline & (3.04) & & $(-2.10)$ & \\
\hline \multirow[t]{2}{*}{ Beach } & -147.3 & & 0.0774 & \\
\hline & $(-0.33)$ & & $(0.31)$ & \\
\hline \multirow[t]{2}{*}{ Playchild } & 221.7 & & -0.121 & \\
\hline & $(0.94)$ & & $(-0.94)$ & \\
\hline \multirow[t]{2}{*}{ Scenic } & $1226.4^{* *}$ & 28.50 & $-0.690^{* *}$ & -0.68 \\
\hline & $(2.16)$ & & $(-2.57)$ & \\
\hline \multirow[t]{2}{*}{ Offroad } & -1024.3 & & 0.628 & \\
\hline & $(-0.87)$ & & $(1.02)$ & \\
\hline \multirow[t]{2}{*}{ Searesort } & 343.6 & & -0.182 & \\
\hline & (0.99) & & $(-0.94)$ & \\
\hline \multirow[t]{2}{*}{ Seacoast } & -569.4 & & 0.271 & \\
\hline & $(-1.09)$ & & $(0.90)$ & \\
\hline \multirow[t]{2}{*}{ Country } & $-424.1^{* *}$ & -462.86 & $0.204^{*}$ & -0.02 \\
\hline & $(-2.23)$ & & $(1.73)$ & \\
\hline \multirow[t]{2}{*}{ Numadults } & $-41.27^{*}$ & 15.80 & $0.0245^{* * *}$ & 0.11 \\
\hline & $(-1.91)$ & & $(2.67)$ & \\
\hline \multirow[t]{2}{*}{ Numchild } & -24.15 & & 0.0130 & \\
\hline & $(-1.06)$ & & $(1.03)$ & \\
\hline \multirow[t]{2}{*}{ Childinhh } & $563.4^{* * *}$ & 248.46 & $-0.299^{* * *}$ & -0.16 \\
\hline & $(2.82)$ & & $(-2.83)$ & \\
\hline
\end{tabular}




\begin{tabular}{|c|c|c|c|c|}
\hline Adultsinhh & $\begin{array}{l}-43.62 \\
(0.51)\end{array}$ & & $\begin{array}{l}0.0290 \\
(063)\end{array}$ & \\
\hline Agemid & -3.356 & & 0.00176 & \\
\hline Workft & $\begin{array}{l}473.4^{* * * *} \\
(2.61)\end{array}$ & 434.38 & $\begin{array}{l}-0.234^{* *} \\
(-2.08)\end{array}$ & -0.02 \\
\hline Whitebritish & $\begin{array}{l}-879.4^{* * *} \\
(-4.36)\end{array}$ & -684.99 & $\begin{array}{l}0.444^{* * *} \\
(3.35)\end{array}$ & 0.11 \\
\hline Socialgradeab & $\begin{array}{l}327.2 \\
(1.95)\end{array}$ & & $\begin{array}{l}-0.161 \\
(-1.61)\end{array}$ & \\
\hline Ownbuyhouse & $\begin{array}{l}288.7 \\
(1.44)\end{array}$ & & $\begin{array}{l}-0.175^{*} \\
(-1.88)\end{array}$ & \\
\hline Sex & $\begin{array}{l}18.91 \\
(0.13)\end{array}$ & & $\begin{array}{l}-0.00724 \\
(-0.09)\end{array}$ & \\
\hline Marital & $\begin{array}{l}793.0^{* * *} \\
(4.33)\end{array}$ & 504.82 & $\begin{array}{l}-0.409^{* * *} \\
(-3.75)\end{array}$ & -0.16 \\
\hline Triptaste & $\begin{array}{l}178.6 \\
(0.66)\end{array}$ & & $\begin{array}{l}-0.119 \\
(-0.84)\end{array}$ & \\
\hline Constant & $\begin{array}{l}-6898.7^{* * *} \\
(-3.23)\end{array}$ & & $\begin{array}{l}3.983^{* * *} \\
(11.97)\end{array}$ & \\
\hline$n$ & & & 5,004 & \\
\hline
\end{tabular}

